\title{
UPAYA MENINGKATKAN HAFALAN PERKALIAN MATEMATIKA DENGAN MENGGUNAKAN METODE BERNYANYI PADA SISWA KELAS 2 SD DI MUHAMMADIYAH 12 PAMULANG BANTEN
}

\author{
Zulfitria \\ Magister Teknologi Pendidikan, Universitas Muhammadiyah Jakarta \\ email: fzulfitria@umj.ac.id
}

\begin{abstract}
Mathematics is one of the most frightening learning for students, the real ability of social teaching is low. One way to improve students' multiplication skills by memorizing multiplication using the singing method.Research to find out how to learn mathematics in multiplication learning through memorizing methods by singing at Muhammadiyah Elementary School 12 Pamulang-Banten. The subject of the study was the second grade students of Al-Farisi class from August to September 2018. The research results obtained from each cycle have expressions from each cycle. This can be done by using the method of memorizing multiplication more pleasant and making it easier for students to remember it. Student students learn the assignments given by the teacher.
\end{abstract}

Keywords: learning, mathematics, methods, singing

\begin{abstract}
Abstrak
Matematika salah satu pembelajaran yang sangat menakutkan bagi siswa, sehingga kemampuan pembelajaran matematika khususnya perkalian menjadi rendah. Salah satu cara untuk meningkatkan kemampuan perkalian siswa dengan cara menghafalkan perkalian mengunakan metode bernyanyi.

Penelitian bertujuan untuk mengetahui upaya peningkatan belajar matematika dalam pembelajaran perkalian melalui metode menghafal dengan bernyanyi di SD Muhammadiyah 12 Pamulang. Subjek penelitian adalah siswa kelas II SD kelas Al-Farisi sejak bulan Agustus-September 2018.

Hasil penelitian yang diperoleh dari tiap siklus bahwa ada peningkatan dari tiap siklus. Hal ini dapat diketahui bahwa dengan menggunakan metode menghafal perkalian dengan bernyanyi lebih menyenangkan dan memudahkan siswa untuk mengingatnya sehingga siswa bersemangat mengerjakan tugas yang diberikan oleh guru.
\end{abstract}

Kata Kunci : pembelajaran, matematika, metode, bernyanyi

\section{PENDAHULUAN}

Menghafal bukan suatu hal yang mudah, karena butuh kosentrasi dan daya ingat yang tinggi, begitu pula dengan belajar. Belajar merupakan proses kegiatan dari tidak tahu menjadi tahu dari tidak bisa menjadi bisa dan dari tidak terampil menjadi terampil. Kegiatan belajar sengaja dilakukan supaya siswa mendapat pengetahuan yang dibutuhkan.

Guru menggunakan bermacam-macam metode pembelajaran untuk memudahkan dalam proses pembelajaran.

Pelajaran matematika merupakan pelajaran yang menakutkan bagi siswa. Salah satu pokok bahasan matematika yang sulit dipahami berupa pokok bahasan perkalian.
Berdasarkan pengamatan penulis di lapangan perlu adanya perubahan strategi pembelajaran di kelas. Belum pahamnya konsep matematika, merupakan salah satu penyebab masih rendahnya hasil belajar siswa kelas 2 SD, khususnya pada materi perkalian.

Pokok bahasan perkalian menjadi sulit karena proses pengenalannya kepada siswa hanya bersifat informatif. Siswa hanya diminta menghafalkan dan mengerjakan soal perkalian dan mencatat dengan berpatokan hafalan. Oleh karena itu, peneliti tertarik untuk mnggunakan metode bernyanyi yang memudahkan siswa menghafal.

Pastilah semua suka bernyanyi dari anak anak, remaja maupun orang dewasa suka 
akan nyanyian. Sejak masuk TK banyak sekali pembelajaran menggunakan bercerita, bermain dan bernyanyi.

Oleh karena itu, peneliti tertarik untuk memilih judul "Upaya Meningkatkan Hapalan Perkalian Matematika Dengan Menggunakan Metode Bernyanyi Pada Siswa Kelas 2 SD Muhammadiyah 12 Pamulang-Banten".

Adapun tujuan penelitian ini adalah:

1. Untuk mengetahui pelaksanaan matematika siswa $2 \mathrm{SD}$

2. Untuk mengetahui hasil belajar matematika siswa dengan menggunakan metode bernyanyi pada pelajaran matematika di kelas 2 SD

Berdasarkan tujuan tersebut maka penelitian ini dapat dirumuskan sebagai berikut: "Bagaimana Upaya Meningkatkan Hapalan Perkalian Matematika Dengan Menggunakan Metode Bernyanyi Pada siswa kelas 2 SD di Muhammadiyah 12 Palulang-Banten?

\section{KAJIAN LITERATUR \\ Hakekat Belajar Matematika}

Matematika itu "susah" sering terdengar keluhan di telinga guru dan orang tua. Siswa beranggapan bahwa matematika itu sulit, membingungkan, dan bikin pusing. Akhirnya beberapa siswa menjadi malas belajar khususnya mata pelajaran matematika.

Menurut Winkel dalam Darsono (2000:73) menyatakan belajar adalah suatu aktivitas mental atau psikis yang berlangsung dalam interaksi aktif dengan lingkungan, menghasilkan perubahan dalam pengetahuan, pemahaman, keterampilan dan sikap. Sedangkan Morgan dalam Purwanto (1992:85) belajar adalah setiap perubahan yang relative tetap dalam waktu yang lama dan tingkah laku tersebut merupakan hasil dari pengalaman atau latihan. Hal ini menunjukkan bahwa siswa dikatakan belajar jika dalam diri siswa terjadi perubahan tingkah laku bersifat tetap yang dipengaruhi oleh adanya rangsangan dan ingatan.

Menurut Syah (2004:196) secara global, faktor yang mempengaruhi keberhasilan belajar siswa dibedakan menjadi tiga macam yakni: Pertama Faktor internal (dalam siswa); yaitu keadaan kondisi jasmani dan rohani siswa. Kedua, Faktor eksternal (luar siswa); yaitu kondisi lingkungan di sekitar siswa. Dan terakhir faktor ketiga yaitu pendekatan belajar; upaya belajar yang meliputi strategi dan model pembelajaran yang digunakan siswa dalam melakukan kegiatan pembelajaran.

Menurut James. L dalam Karso (2005:129) matematika berasal dari bahasa Yunani mathein atau manthenein yang artinya mempelajari, dalam kata sansekerta medha atau widya yang artinya kepandaian, ketahuan, atau intelegensi.

Dalam Depdikbud (1996:57) Mata pelajaran matematika berfungsi untuk mengembangkan kemampuan berkomunikasi berupa bilangan, simbolsimbol berupa ketajaman penalaran yang dapat membantu menyelesaikan permasalahan kehidupan sehari-hari.

Menurut Auliya (2009:8) perkalian merupakan operasi penjumlahan yang diulang-ulang. Dalam kamus Bahasa Indonesia Kali adalah tanda (x) untuk menyatakan pergandaan (perbanyakan), memperbanyakkan bilangan, berulangulang. Perkalian merupakan seluruh bilangan di dalam suku-suku perjumlahan yang diulang-ulang, misalnya; $3 \mathrm{X} \quad 4$ (dibaca "3 kali 4") dapat dihitung dengan angka 4 berulang sebanyak 3 bersamasama, seperti ini contohnya:

$$
3 \times 4=4+4+4=12
$$

Sebagai acuannya adalah konsep-konsep operasi hitung perkalian pada sistem bilangan cacah. Pada perkalian bilanganbilangan cacah, beberapa sifat bilangan, sebagai berikut, yaitu:

1. Komutatif, artinya untuk setiap bilangan cacah a dan b berlaku a x b $=\mathrm{b} \times \mathrm{a}$ Contoh: 5 × $4=4$ × 5 hasilnya akan sama yaitu masing-masing 20

2. Sosiatif, artinya untuk setiap bilangan cacah $\mathrm{a}, \mathrm{b}$ dan $\mathrm{c}$ berlaku $(\mathrm{a} \times \mathrm{b}) \mathrm{x} \mathrm{c}=\mathrm{a} \mathrm{x}$ $(\mathrm{b} \times \mathrm{c})$ 
Contoh: $(5 \times 4) \times 3=5 \times(4 \times 3)$ hasilnya akan sama yaitu masingmasing 60

3. Adanya unsure identitas, yaitu 1, artinya untuk setiap bilangan cacah a jika dikali 1 hasilnya bilangan cacah tersebut.

Contoh: jika a adalah 5 , maka 1 x $5=5$

\section{Hakekat Metode Bernyanyi}

Pasti semua orang bisa bernyanyi, walaupun hanya bersenandung di hati. Menyanyi menurut Trantranurandi (2011:31) adalah melafadzkan suatu kata atau kalimat yang dinyanyikan.

Sedangkan menurut Matondang (1996:129) bahwa "bernyanyi adalah kegiatan yang sangat menyenangkan dan bisa menumbuhkan semangat. Maka bernyanyi merupakan metode yang menekankan pada kata-kata yang dilagukan dengan suasana yang menyenangkan sehingga ketika pembelajaran siswa tidak jenuh dalam mengikuti pembelajaran. Melalui bernyanyi akan memotivasi anak untuk senang dan lebih mudah dalam memahami materi akan yang disampaikan.

Menyanyi bagian dari ungkapan emosi, baik senang maupun sedih. Manfaat menyanyi menurut Rahman (2005:90) sebagai alat dan media pembelajaran. Sedangkan Menurut Achmad (1994:10) Tujuan bernyanyi adalah untuk memupuk perasaan irama, perasaan estetis, memperkaya perbendaharaan bahasa, melatih daya ingat, memberikan kepuasan, kebahagiaan, sehingga dalam pembelajaran dapat mendorong siswa untuk belajar lebih semangat.

Langkah-langkah dalam pelaksanaan pembelajaran menghafal dengan metode bernyanyi adalah sebagai berikut: (1) Guru melakukan apersepsi bisa dengan yel yel, (2) Guru melakukan tanya jawab sesuai dengan tema yang akan di ajarkan, (3) Guru mencontohkan nyanyian yang dihubungkan dengan materi pelajaran, (4) Anak-anak memperhatikan kata-kata yang ada dalam lirik lagu yang dinyanyikan oleh guru, (5) Selanjutnya Para siswa mengikuti nyanyian yang tadi sudah dicontohkan oleh guru, (6)
Guru menyanyikan kembali lagu agar siswa mengingat kembali, (7) Para siswa menyimak lagu yang dinyanyikan oleh guru, (8) Para siswa bersama guru menyanyikan kembali lagu bersama-sama, (9) dan sebagai evaluasi Guru menunjuk beberapa siswa untuk maju ke depan dan mengulang bernyanyi lagu tersebut.

\section{METODE PENELITIAN}

Penelitian dilaksanakan di SD Muhammadiyah 12 Pamulang Tangerang Selatan-Banten yang berlokasi Jln Surya Kencana No.29 Pamulang-Banten 15417. Penelitian ini dilakukan pada bulan JuliSeptember 2018 di kelas II Al Farabi berjumlah 30 siswa.

Jenis penelitian ini adalah tindakan (action research). Menurut Wardani (2005:14) penelitian tindakan kelas adalah penelitian yang dilakukan oleh guru di kelasnya sendiri melalui refleksi diri dengan tujuan untuk memperbaiki kinerjanya sehingga hasil belajar siswa meningkat.

Desain yang digunakan dalam penelitian ini adalah jenis Penelitian Tindakan Kelas (PTK). Keberhasilan siswa dapat dilihat melalui hasil belajar. Alur pelaksanaan tindakan dalam penelitian ini dapat dilihat sebagai berikut:

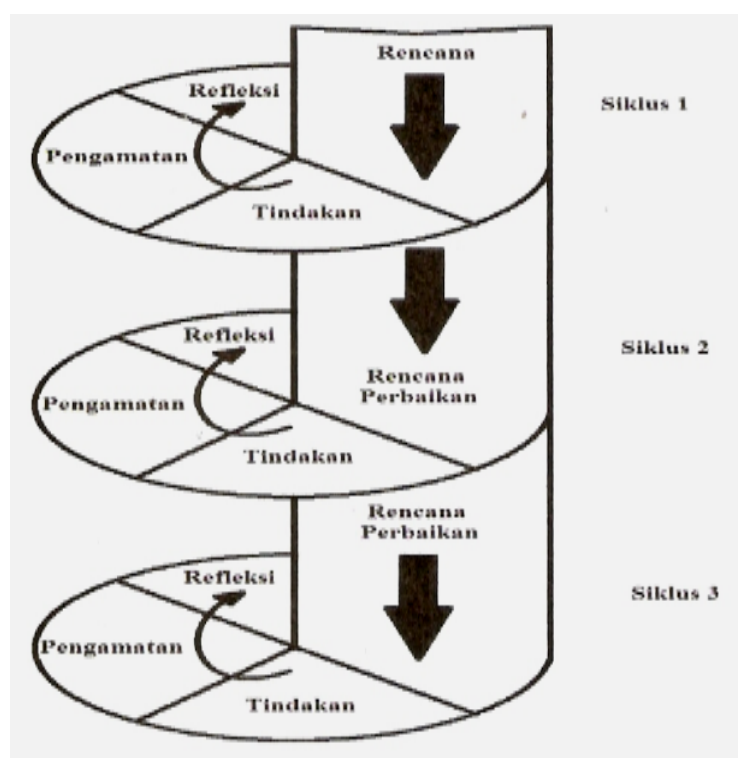

Gambar 1.Alur pelaksanaan tindakan penelitian Mac Isaac (2005) 
Adapun teknik pengumpulan data yang dilakukan peneliti untuk memperoleh data yang diperlukan dengan cara:

1. Observasi

Observasi yang dilakukan pada penelitian ini adalah partisipan dengan teman sekerja sebagai observer dengan menggunakan instrument pengamatan setiap siklus. Observer melihat langsung keadaan pembelajaran yang dilakukan oleh siswa kelas II Sekolah Dasar. Pengamatan terhadap partisipasi siswa, kegiatan guru dalam pembelajaran, dan pengamatan terhadap suasana belajar di lingkungan sekolah.

2. Wawancara

Wawancara dilakukan terhadap beberapa siswa yang dilaksanakan pada siklus I untuk mengambil informasi yang lebih mendalam dan intensif tentang kegiatan pembelajaran Matematika pada kelas 2 Al Farabi SD Muhammadiyah 12 Pamulang-Banten

3. Studi Dokumentasi

Untuk memperkuat data dan hasil observasi dan wawacara, peneliti juga menggunakan studi dokumentasi yang berupa foto kegiatan pembelajaran per siklus dan lingkungan suasana belajar di kelas 2 Al Farabi SD Muhammadiyah 12 Pamulang-Banten

\section{HASIL DAN PEMBAHASAN}

Penelitian dilakukan pra siklus lalu kemudian diberi metode bernyanyi terdiri dari 3 siklus, yaitu: siklus I, siklus II dan siklus 3 .

Sebelum melakukan penelitian tindakan kelas, peneliti terlebih dahulu melakukan observasi dan identifikasi masalah terhadap situasi dan kondisi pembelajaran di kelas. Berdasarkan hasil observasi didapat identifikasi masalah antara lain :

a. Dalam pengkondisian kelas dirasakan belum kondusif mungkin sudah terbiasa dengan keadaan yang konvensional.

b. Dalam proses pembelajaran, ternyata siswa kurang aktif dan kurang semangat dalam belajar karena kegiatan yang dilakukan monoton seperti mendengarkan penjelasan guru dan mencatatnya.

c. Dalam tanpa jawab siswa kurang percaya diri untuk mengemukakan pendapatnya.

d. Hasil akhir pembelajaran Matematika belum mencapai KKM yaitu 7

Tabel 4. 1 (Pra Siklus)

\begin{tabular}{|c|c|c|c|}
\hline No. & Nama Siswa & Pra Siklus & Tuntas (70) \\
\hline 1 & AKA & 70 & $\mathrm{~T}$ \\
\hline 2 & AIK & 40 & $\mathrm{~L}$ \\
\hline 3 & AAS & 70 & $\mathrm{~T}$ \\
\hline 4 & ABS & 50 & $\mathrm{~L}$ \\
\hline 5 & $\mathrm{AF}$ & 80 & $\mathrm{~T}$ \\
\hline 6 & ASL & 70 & $\mathrm{~T}$ \\
\hline 7 & $\mathrm{AL}$ & 40 & $\mathrm{~L}$ \\
\hline 8 & AN & 30 & $\mathrm{~L}$ \\
\hline 9 & $\mathrm{CH}$ & 40 & $\mathrm{~L}$ \\
\hline 10 & $\mathrm{DA}$ & 70 & $\mathrm{~T}$ \\
\hline 11 & DAS & 60 & $\mathrm{~L}$ \\
\hline 12 & DP & 70 & $\mathrm{~T}$ \\
\hline 13 & DF & 20 & $\mathrm{~L}$ \\
\hline 14 & FPS & 30 & $\mathrm{~L}$ \\
\hline 15 & BLN & 60 & $\mathrm{~L}$ \\
\hline 16 & IA & 80 & $\mathrm{~T}$ \\
\hline 17 & NFF & 70 & $\mathrm{~T}$ \\
\hline 18 & NPW & 30 & $\mathrm{~L}$ \\
\hline 19 & $\mathrm{MB}$ & 40 & $\mathrm{~L}$ \\
\hline 20 & FN & 40 & $\mathrm{~L}$ \\
\hline 21 & NAR & 60 & $\mathrm{~L}$ \\
\hline 22 & $\mathrm{~N}$ & 70 & $\mathrm{~T}$ \\
\hline 23 & PP & 70 & $\mathrm{~T}$ \\
\hline 24 & RMG & 80 & $\mathrm{~T}$ \\
\hline 25 & SS & 20 & $\mathrm{~L}$ \\
\hline 26 & SRA & 30 & $\mathrm{~L}$ \\
\hline 27 & SA & 40 & $\mathrm{~L}$ \\
\hline 28 & SKR & 50 & $\mathrm{~L}$ \\
\hline 29 & $\mathrm{~W}$ & 50 & $\mathrm{~L}$ \\
\hline \multirow[t]{2}{*}{30} & $\mathrm{R}$ & 60 & $\mathrm{~L}$ \\
\hline & Jumlah & 1590 & 11 \\
\hline
\end{tabular}




\begin{tabular}{|l|l|}
\hline $\begin{array}{l}\text { Presentase siswa yang } \\
\text { Mencapai KKM (70) }\end{array}$ & $\mathbf{3 6 , 6 7 \%}$ \\
\hline Pada tabel di atas, dapat dilihat bahwa
\end{tabular}

Pada tabel di atas, dapat dilihat bahwa jumlah siswa yang mencapai kriteria ketuntasan minimal masih sedikit, baru sebanyak 11 siswa atau $36,67 \%$.

Pelaksanaan metode bernyanyi pada siklus 1 Keterangan Skor :

$$
\begin{array}{llll}
4 & =\text { Sangat baik } & 3 & =\text { Baik } \\
2 & =\text { Cukup } & 1 & =\text { Kurang }
\end{array}
$$

\section{Gambar 4.1}

Diagram hasil belajar matematika Siklus 1

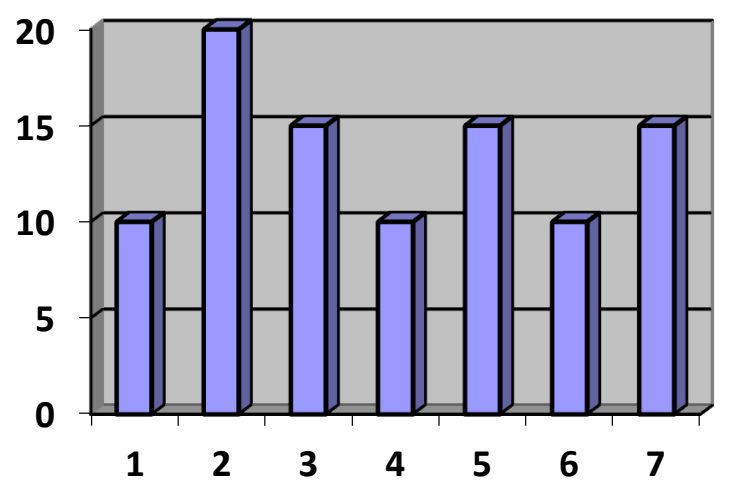

Keterangan diagram :

1. Mengenal perkalian sebagai penjumlahan berulang

2. Menghitung secara cepat perkalian bilangan dua angka

3. Mengingat fakta perkalian sampai $5 \mathrm{x}$ 10 dengan berbagai cara.

4. Bentuk perkalian menjadi bentuk pembagian

5. Membaca dan menggunakan simbol $X$ dalam pengerjaan hitung

6. Menuliskan bilangan dua angka dalam bentuk panjang

7. Memecahkan soal cerita yang mengandung perkalian

\begin{tabular}{|c|c|c|c|c|c|c|c|c|}
\hline \multirow[b]{2}{*}{$\begin{array}{l}\mathrm{N} \\
\mathrm{o}\end{array}$} & \multirow[b]{2}{*}{ Aspek Penilaian } & \multicolumn{5}{|c|}{ Hasil Pengamatan } & \multirow{2}{*}{$\begin{array}{l}\text { Rata } \\
\text {-rata }\end{array}$} & \multirow{2}{*}{$\%$} \\
\hline & & 4 & 3 & 2 & 1 & JML & & \\
\hline 1 & $\begin{array}{l}\text { Mengenal } \\
\text { perkalian } \\
\text { sebagai } \\
\text { penjumlahan } \\
\text { berulang. }\end{array}$ & 2 & 2 & 8 & 8 & 670 & 33,5 & $\begin{array}{l}10 \\
\%\end{array}$ \\
\hline 2 & \begin{tabular}{l}
\multicolumn{2}{c}{ Menghitung } \\
secara cepat \\
perkalian \\
bilangan dua \\
angka.
\end{tabular} & 3 & 5 & 8 & 4 & 820 & 41 & $\begin{array}{l}20 \\
\%\end{array}$ \\
\hline 3 & $\begin{array}{l}\text { Mengingat fakta } \\
\text { perkalian } \\
\text { sampai } 5 \times 10 \\
\text { dengan berbagai } \\
\text { cara. }\end{array}$ & 3 & 6 & 6 & 5 & 870 & 43,5 & $\begin{array}{l}15 \\
\%\end{array}$ \\
\hline 4 & $\begin{array}{l}\text { Bentuk } \\
\text { perkalian } \\
\text { menjadi bentuk } \\
\text { pembagian. }\end{array}$ & 2 & 1 & 9 & 6 & 640 & 32 & $\begin{array}{l}10 \\
\%\end{array}$ \\
\hline 5 & $\begin{array}{l}\text { Membaca dan } \\
\text { menggunakan } \\
\text { simbol X dalam } \\
\text { pengerjaan } \\
\text { hitung. }\end{array}$ & 3 & 5 & 5 & 7 & 830 & 41,5 & $\begin{array}{l}15 \\
\%\end{array}$ \\
\hline 6 & \begin{tabular}{l}
\multicolumn{2}{c}{ Menuliskan } \\
bilangan dua \\
angka dalam \\
bentuk panjang.
\end{tabular} & 2 & 3 & 7 & 4 & 630 & 31,5 & $\begin{array}{l}10 \\
\%\end{array}$ \\
\hline 7 & $\begin{array}{l}\text { Memecahkan } \\
\text { soal cerita yang } \\
\text { mengandung } \\
\text { perkalian. }\end{array}$ & 4 & 8 & 6 & 1 & $\begin{array}{l}1.08 \\
0\end{array}$ & 54 & $\begin{array}{l}20 \\
\%\end{array}$ \\
\hline
\end{tabular}

Pelaksanaan metode bernyanyi pada siklus 2

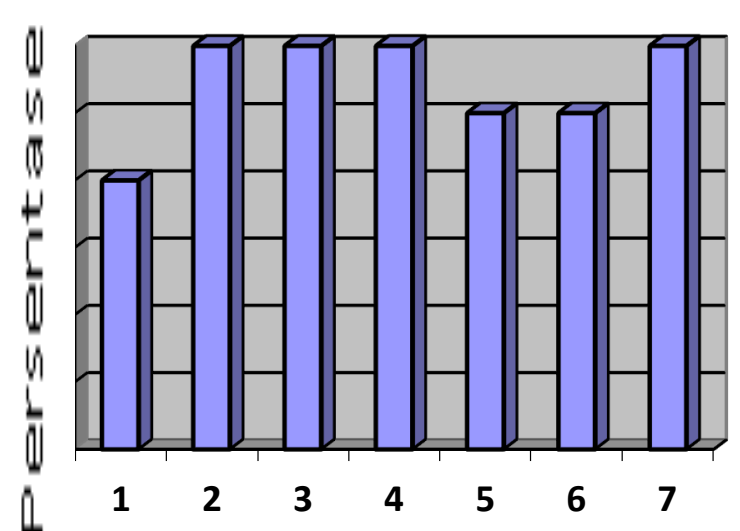


Keterangan diagram :

1. Mengenal perkalian sebagai penjumlahan berulang

2. Menghitung secara cepat perkalian bilangan dua angka

3. Mengingat fakta perkalian sampai $5 \mathrm{x}$ 10 dengan berbagai cara.

4. Bentuk perkalian menjadi bentuk pembagian

5. Membaca dan menggunakan simbol X dalam pengerjaan hitung

6. Menuliskan bilangan dua angka dalam bentuk panjang

7. Memecahkan soal cerita yang mengandung perkalian

\section{Gambar 4.3}

Pelaksanaan metode bernyanyi pada siklus 3

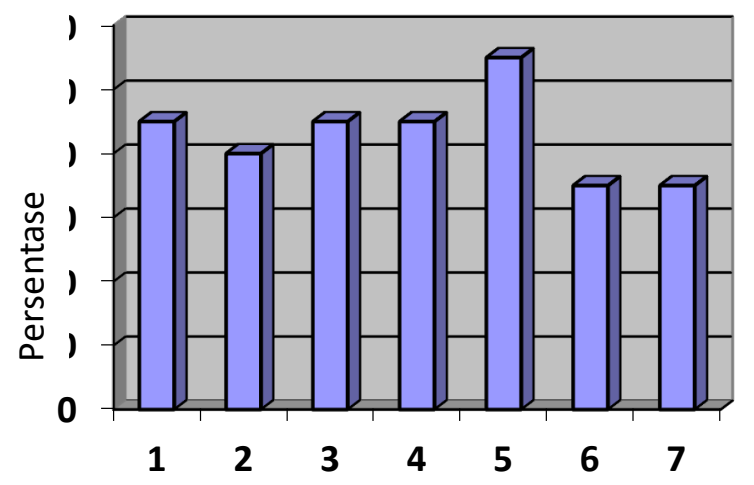

Keterangan diagram :

1. Mengenal perkalian sebagai penjumlahan berulang

2. Menghitung secara cepat perkalian bilangan dua angka

3. Mengingat fakta perkalian sampai $5 \mathrm{x}$ 10 dengan berbagai cara.

4. Bentuk perkalian menjadi bentuk pembagian

5. Membaca dan menggunakan simbol $\mathrm{X}$ dalam pengerjaan hitung

6. Menuliskan bilangan dua angka dalam bentuk panjang

7. Memecahkan soal cerita yang mengandung perkalian

\section{Analisis Data Hasil Penelitian}

Setelah melakukan evaluasi baik proses maupun hasil belajar matematika dilakukan analisis data.

Tabel 4.4 Distribusi Siklus 1 sampai siklus 3

\begin{tabular}{|l|l|l|}
\hline No & Siklus & $\begin{array}{l}\text { Jumlah siswa yang } \\
\text { memperoleh nilai 7,5 }\end{array}$ \\
\hline 1 & Pertama & 13 orang \\
\hline 2 & Kedua & 20 orang \\
\hline 3 & Ketiga & 26 orang \\
\hline
\end{tabular}

Diagram batang sebelum dan sesudah menggunakan metode bernyanyi dalam menghafal perkalian matematika:

Rata - rata Nilai

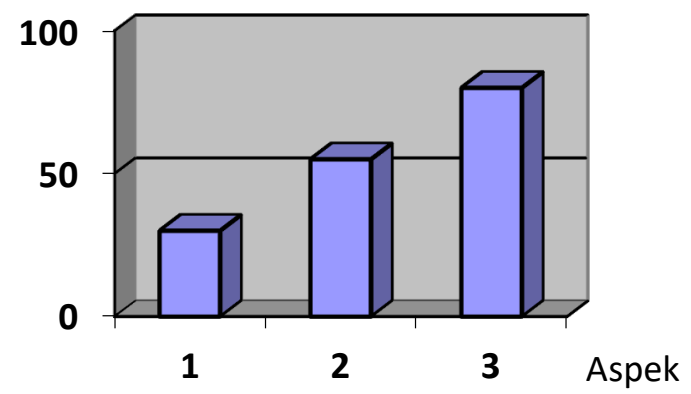

\section{Interprestasi Hasil Analisis dan Pembahasan \\ Siklus pertama}

Dari hasil analisis data pada siklus pertama nilai post test $30 \%$ nilai 7,5 baru dicapai oleh 13 orang. Sedangkan pada siklus kedua dengan nilai post test $55 \%$, nilai 7,5 telah dicapai oleh 20 orang, sehingga terdapat peningkatan hasil belajar siswa dibandingkan siklus pertama, namun perubahan tersebut belum mencapai target. Sesuai dengan perencanaan tindakan penelitian dilakukan pada siklus ke dua.

\section{Siklus kedua}

Dari hasil analisa data pada siklus kedua nilai post tes $55 \%$, dengan 20 orang mencapai nilai 7,5 terdapat 
peningkatan dibandingkan pada siklus pertama, namun perubahan tersebut belum mencapai target. Sesuai dengan perencanaan tindakan penelitian dilakukan pada siklus ke tiga.

\section{Siklus ke tiga}

Dari analisis data pada siklus kedua nilai 7,5 baru dicapai oleh 20 orang sedangkan pada siklus ke tiga dengan post test $80 \%$ dan 26 orang sudah mencapai nilai 7,5 sehingga terdapat peningkatan hasil belajar siswa dibandingkan siklus kedua. Pada siklus ketiga ini baik aspek efektivitas pembelajaran maupun hasil belajar terlihat kenaikan yang cukup baik.

Dari rangkaian pengujian yang dilakukan oleh peneliti ditemukan beberapa hal tantang pembelajaran matematika dalam perkalian. Pembelajaran perkalian dapat meningkat, jika guru mampu menggunakan metode yang tepat.

Melalui metode bernyanyi siswa lebih tertarik karena situasi belajar yang menyenangkan.

Dari rangkaian pengujian yang dilakukan oleh peneliti ditemukan beberapa hal tantang pembelajaran matematika dalam perkalian. Pembelajaran perkalian dengan metode bernyanyi dapat meningkatkan hasil belajar dibandingkan dengan belajar secara konvensional berupa ceramah maupun mencatat.

Menyanyi sebagai metode pembelajaran dalam penelitian ini ternyata cukup membantu meningkatkan hasil belajar siswa pada pembelajaran matematika.

\section{KESIMPULAN}

Berdasarkan hasil penelitian dan analisis data, disertai dengan pengujian hipotesis dan korelasi, maka dapat diambil beberapa kesimpulan sebagai berikut:

1. Melalui penelitian yang mengukur tingkat upaya peningkatan metode bernyanyi diterapkan terhadap siswa pada pembelajaran matemtika konsep menghafal perkalian hasilnya lebih baik karena mebantu siswa memudahkan penghafalan serta lebih semangat dalam pembelajaran matematika.

2. Siswa di kelas 2 Al Farisi lebih meningkat motivasi belajarnya dan tingkat pemahaman terhadap materi yang disampaikan. Sehingga siswa berharap metode bernyanyi dalam proses belajar mengajar bisa selalu diterapkan.

3. Membuat media pembelajaran untuk mempermudah siswa khusus untuk soal cerita pada perkalian. Siswa lebih memahami teori dan langkah-langkah pengerjaan soal dengan memberi menghafal perkalian samabil bernyanyi.

\section{REFERENSI}

Achmad, Ali . 1994. Pendidikan Bahasa di $T K$. Depdikbud, Jakarta.

Auliya, M. Fajar. 2009. Jari Magic; Berhitung Dahsyat dengan Jari.Yogyakarta:Pustaka Widyatama.

Darsono. 2000. Belajar dan Pembelajaran. Semarang: JKJP Semarang Press.

Depdikbud. 1996. Penyelenggaraan Pendidikan Di Sekolah Dasar.Jakarta:Dirjen Pendidikan Dasar dan Menengah.

Karso. 2005. Pendidikan Matematika I. Jakarta: Universitas Terbuka.

Matondang, Elisabeth Marsaulina. 1996. Jurnal Pendidikan BPK.Tangerang.

MacIssac, $2005.2 T h e$ ActionResearchProcess"(http://web.net//roobrien/papers/arfina1.htm1)

Purwanto, Ngalim. 1992. Psikologi Pendidikan. Bandung: Remaja Rosdakazya. 
Rahman, Hibana. 2005. Konsep Dasar Pendidikan Anak Usia Dini. Yogyakarta: Grafindo Litera Media.

Syah, Muhibbin. 2004. Psikologi Belajar. Jakarta: Rajawali Pers

Trantranurandi, Pembelajaran Menghafal dengan
Singing
Methode,

2011/2/25/pembelajaran-dEngan-singingmethode. 